\title{
Misterium Chrystusa, kerygmat i dogmat w przepowiadaniu
}

\section{Wprowadzenie}

Do istoty Kościoła należy przepowiadanie słowa Bożego. A co stanowi treść chrześcijańskiego przepowiadania: kerygmat, dogmat, misterium Chrystusa? Dla niektórych głoszenie kerygmatu nabrało takiego znaczenia, że aż do przesady chcą sprowadzić do niego całe przepowiadanie. W krótkim eseju Kerygmat dobry na wszystko ${ }^{1}$ Gerard Siwek (1938-2015) zauważył, że istnieją propozycje głoszenia kerygmatu ,jako panaceum na wszelkie bolączki polskiego katolicyzmu”2. Zwolennicy sprowadzenia całego przepowiadania Kościoła do głoszenia kerygmatu argumentują, że pomimo intensywnej katechizacji mamy do czynienia z przerażającą ignorancją religijną wiernych. Rodzi się więc pytanie o sens takiego katechizowania, „gdyż jest

1 G. Siwek, Blaski i cienie współczesnego przepowiadania. Przewodnik dla kaznodziejów i homilistów, Kraków 2007, s. 58-62.

2 Tamże, s. 58. 
właściwie katechizowaniem niewierzących, których trzeba najpierw doprowadzić do wiary, następnie katechizować” ${ }^{3}$.

Ale obok zwolenników kerygmatu, nie brakuje teologów, którzy utrzymują, że należy wyjaśniać słuchaczom dogmaty, mówić, w co mają wierzyć i pomagać w zrozumieniu wiary ${ }^{4}$. Racjonalne uzasadnienie wiary i wyjaśnienie jej dogmatów jest potrzebne tym bardziej, że w naszych czasach widać wzrastającą teologiczną ignorancję wiernych ${ }^{5}$. Mając tę świadomość, papież Benedykt XVI w adhortacji Sacramentum Caritatis (22.02.2007) zwrócił uwagę na konieczność poprawienia jakości homilii, przynaglając jednocześnie do unikania homilii ogólnych i abstrakcyjnych oraz do uwzględniania katechetycznego celu homilii: „Jest wskazane, by wychodząc od trzyletniego cyklu lekcjonarza, przedstawiano wiernym w sposób właściwy homilie tematyczne, w których omówiono by w ciągu roku liturgicznego wielkie zagadnienia wiary chrześcijańskiej. Treść do nich należy czerpać w sposób pewny z Magisterium w oparciu o cztery «filary» określone przez Katechizm Kościoła Katolickiego i niedawno ogłoszone Kompendium, a więc: wyznanie wiary, celebracja misterium chrześcijańskiego, życie w Chrystusie, modlitwa chrześcijańska" (SCar, 46) ${ }^{6}$.

O ile papież Benedykt akcentuje „zagadnienia wiary chrześcijańskiej” i „Magisterium”, o tyle nauczanie II Soboru Watykańskiego, który przywrócił homilię jako część liturgii, podkreśla, że homilia powinna czerpać swoją treść przede wszystkim ze źródeł Pisma Świętego i liturgii ,jako zwiastowanie przedziwnych dzieł Bożych w dziejach zbawienia, czyli w misterium Chrystusowym, które zawsze jest w nas

3 Tamże.

4 W. J. Carl III, Preaching Christian doctrine, Philadelphia 1984, s. 3.

5 J. A. Wallace, Imaginal preaching. An archetypal perspective, New York-Mahwah 1995, s. 12.

6 Por. H. Sławiński, Między ciaggłościq a zmianq. Teoria homilii w Stanach Zjednoczonych po Il Soborze Watykańskim, Kraków 2008, s. 83-87. 
obecne i działa, zwłaszcza w obrzędach liturgicznych" (KL 35, 2). Również Kodeks prawa kanonicznego, ujmujący soborowe nauczanie w precyzyjnych sformułowaniach, wskazał na misterium Chrystusa jako centrum wszelkiej posługi słowa. Według tego kodeksu: „W posłudze słowa, która winna się opierać na Piśmie Świętym, Tradycji, liturgii, Nauczycielskim Urzędzie i życiu Kościoła, należy przedstawiać w całości i wiernie tajemnicę Chrystusa” (KPK, kan. 760).

Co zatem jest istotą przepowiadania: kerygmat, dogmat czy misterium Chrystusa? Co dokładnie oznacza głoszenie misterium czy tajemnicy Chrystusa? Jaka jest znaczenie kerygmatu i dogmatu w przepowiadaniu misterium Chrystusa? Odpowiadając na te pytania, najpierw omówimy rozumienie misterium Chrystusa w Kościele, następnie przybliżymy istotę kerygmatu i jego cechy, później zanalizujemy czym jest dogmat i wreszcie przedstawimy, jakie jest znaczenie kerygmatu i dogmatu w głoszeniu misterium Chrystusa, które jest sednem przepowiadania.

\section{Misterium Chrystusa}

\subsection{Znaczenie terminu "misterium”}

Grecki termin mystérion (gr. $\mu$ $\sigma \tau \eta \dot{\rho}\llcorner\mathrm{v}$ ) jest używany w teologii w dwóch znaczeniach. W pierwszym, intelektualnym, oznacza prawdę niepojętą do końca dla ludzkiego umysłu, jak na przykład misterium Trójcy Świętej. W drugim, kultycznym, dotyczy zbawczej rzeczywistości dokonującej się w celebracji liturgicznej. Termin $m y$ stérion występuje w Nowym Testamencie zaledwie 28 razy i to głównie w pismach św. Pawła7.

7 Por. R. Gerardi, Misterio, w: Diccionario teológico enciclopédico, red. L. Pacomi, V. Mancuso, Villatuerta 1995, s. 642-643. Znamienne, że obszerny Leksykon liturgii B. Nadolskiego (Poznań 2002) nie zawiera hasła "misterium”. 
Misterium w znaczeniu kultycznym to nie tyle coś ukrytego i niewyjaśnionego, ale raczej planowe, ale niepojęte dla człowieka działanie Boga (por. Rz 16, 25; Ef 1, 9; 3, 9; Kol 1, 26-27; 2, 2; 4, 3). Ów plan Boga wobec ludzi realizowany jest progresywnie, $\mathrm{z}$ optymalną intensywnością i w optymalnym zakresie, aż osiągnie zamierzony cel ${ }^{8}$. Mówiąc zaś o misterium Chrystusa, mamy na myśli odwieczne postanowienie Boga Ojca, mające na celu doprowadzenie całej ludzkości do poznania prawdy i do zbawienia przez zjednoczenie jej w Chrystusie (por. Ef 1,10$)^{9}$. Święty Paweł określa misterium Chrystusa „tajemniczym planem” (por. Ef 3, 9), „a tradycja patrystyczna «ekonomią Słowa Wcielonego» lub «ekonomią zbawienia»" (KKK 1066). Plan ten ma być ogłoszony wszystkim ludziom (por. Rz 16, 26; Ef 3, 9). Ma on wymiar kosmiczny (por. Ef 3,10$)^{10}$.

Pisarze chrześcijańscy, aż do IV wieku, posługiwali się terminem mystérion w pierwotnym znaczeniu biblijnym, czyli w sensie Bożego planu zbawienia wypełnionego w Jezusie Chrystusie. Jednakże termin ten przechodził ewolucję. Już św. Ignacy Antiocheński (ok. 30-107) posługiwał się terminem mystérion nie tylko w odniesieniu do samej osoby Jezusa, ale także do Jego śmierci i zmartwychwstania. Stopniowo znaczenie terminu było poszerzane tak, że obejmowało poszczególne akty Odkupienia, na przykład Narodzenie czy Ukrzyżowanie.

Ponieważ w owym czasie misteriami nazywane były kultyczne obrzędy pogan, z tego względu św. Justyn (ok. 100-165) nigdy nie posługiwał się terminem mystérion w znaczeniu kultycznym, czyli w odniesieniu do chrześcijańskich celebracji liturgicznych, podkreślając

8 Por. R. Gerardi, Misterio, dz. cyt., s. 642; zob. S. Dyk, Znaczenie terminu "misterium” w refleksji teologiczno-liturgicznej, „Roczniki Liturgiczno-Homiletyczne” 56 (2009) nr 1, s. 69-85.

9 S. Czerwik, Homilia o misterium (misteriach) Chrystusa w cyklu roku liturgicznego, „Przegląd Homiletyczny" 8 (2004), s. 50-51; por. KKK 1066.

10 Por. R. Gerardi, Misterio, dz. cyt., s. 642. 
w ten sposób ich całkowitą odmienność wobec misteriów pogańskich. Podobną ostrożność zachowywał Tertulian (†ok. 220). Obydwaj pisarze rozumieli, że chrześcijańska celebracja chrześcijańska jest kultycznym uobecnieniem jedynego, historycznego i niepowtarzalnego aktu zbawczego dokonanego przez Jezusa Chrystusa ${ }^{11}$.

Autorem chrześcijańskim, który jako pierwszy adaptował termin mystérion na oznaczenie wiary i praktyki chrześcijańskiej był Klemens Aleksandryjski (ok. 150 - ok. 215). Wyraźnie odróżnił misteria chrześcijańskie od adresowanych do fałszywych bóstw obrzędów pogańskich, które były określane przez nich misteriami, ponieważ reprezentowały rzeczywistości święte za pośrednictwem znaków podpadających pod zmysły. Z czasem mystérion zyskał znaczenie określające uświęcające obrzędy chrześcijańskie. Najprecyzyjniej natomiast omawiany termin stosuje się do sakramentów, ponieważ misterium zbawienia dostępne jest $\mathrm{w}$ historii zbawienia dokonującej się w obrzędach sakramentalnych.

Zarówno w epoce patrystycznej jak i po niej zdarzało się używanie terminu mystérion w odniesieniu do dogmatów, w tym sensie, że nie mogą być one do końca zgłębione intelektualnie przez wierzących, ani sprofanowane przez heretyków. Negatywną konsekwencją takiego rozumienia terminu „misterium” było oddzielenie go od terminu „kerygmat”, podczas gdy św. Paweł odnosił obydwa terminy do tej samej rzeczywistości ${ }^{12}$.

Termin „misterium” odzyskał swe centralne znaczenie w teologii i praktyce chrześcijańskiej dzięki soborowej konstytucji Sacrosanctum concilium (por. KL 5-6) oraz posoborowej odnowie liturgicznej. Oznacza on zbawcze działanie Chrystusa oraz jego proklamację i realizację w kulcie Kościoła, w działalności Kościoła i w życiu chrześ- 
cijańskim, jako rzeczywistości centralnej i jednoczącej wiarę i życie chrześcijańskie ${ }^{13}$.

\subsection{Misterium Chrystusa i misteria odkupienia}

Za soborową konstytucją Sacrosanctum concilium rozróżnia się zawarte w roku liturgicznym „całe misterium Chrystusa”, wyrażone w liczbie pojedynczej, oraz w liczbie mnogiej „misteria odkupienia” (KL 102). Wyrażone w liczbie pojedynczej „misterium Chrystusa”, stanowiące centrum całej zbawczej ekonomii, jest treścią obchodu roku liturgicznego. Natomiast określenie w liczbie mnogiej: „misteria odkupienia” oznacza poszczególne wydarzenia z życia Jezusa na ziemi, mające sens zbawczy z racji ich odniesienia do Jego paschy. Innym określeniem misteriów odkupienia w nauczaniu soborowym jest „roczny cykl misteriów Chrystusa” (KL 102).

Misterium Chrystusa jest wprawdzie wydarzeniem jednorazowym, ale za sprawą Ducha Świętego obecnego w Kościele jest ono aktualizowane i odsłaniane przez Kościół z biegiem roku liturgicznego. Posługując się obrazem, można powiedzieć, że rok liturgiczny to jakby rozszczepienie w pryzmacie białego światła misterium paschalnego na wiele barwnych promieni. Każde z misteriów ziemskiego życia Jezusa celebrowane w liturgii ma odniesienie do Jego paschy: wskazuje na nią i czerpie z niej swój sens.

W misteriach odkupienia wyróżniamy wymiar ludzki i boski. W wymiarze ludzkim chodzi o należące do historii fakty z życia Jezusa, zrealizowane w określonym miejscu i czasie. Natomiast w wymiarze boskim chodzi o zbawcze znaczenie owych wydarzeń, a więc ich skutki wykraczające poza czas i przestrzeń. Historyczne wydarzenia z życia Chrystusa, które były Jego osobistymi aktami, stanowią 
rzeczywistość utrwaloną na wieki w Jego uwielbionej egzystencji ${ }^{14}$. Nazywamy je misteriami, bo mają one sens zbawczy dla Kościoła; wywierają wpływ na życie tych, którzy w nich uczestniczą.

W związku z tym istnieje zdecydowana różnica między celebrowaniem misterium Chrystusa, czyli świętowaniem na sposób misterium i każdym innym świętowaniem. Jubileusze różnych wydarzeń wspominamy. W tym sensie wspominamy na przykład rocznicę narodzin świętych dla nieba: czerpiemy z nich przykład, oddajemy im cześć i doznajemy ich wstawiennictwa u Boga. Natomiast specyfika świętowania na sposób misterium polega na tym, że gdy celebrujemy wydarzenia z życia Chrystusa, to podkreślamy ich oddziaływanie na nasze życie. Mówiąc krótko, świętych wspominamy, a misteria Chrystusa aktualizujemy ${ }^{15}$.

\section{Kerygmat}

\subsection{Znaczenie terminu „kerygmat”}

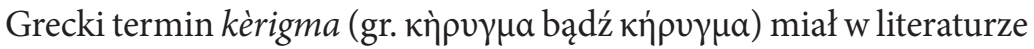
antycznej podwójne znaczenie: oznaczał tak treść głoszonego orędzia, jak i samą czynność głoszenia. W wielu wypadkach trudno jest rozróżnić, które ze znaczeń terminu kerygma należałoby wyakcentować ${ }^{16}$. W Septuagincie kèrigma mogła być urzędowym ogłoszeniem kapłana

14 Por. S. Czerwik, Homilia o misterium (misteriach) Chrystusa w cyklu roku liturgicznego, "Przegląd Homiletyczny” 8 (2004), s. 51.

15 Por. J. Kudasiewicz, Homilie na święta Pańskie a problem synoptyczny, "Przegląd Homiletyczny" 8 (2004), s. 34; H. Sławiński, Między ciągłościq̨..., s. 43-44.

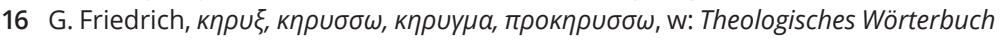
zum Neuen Testament, t. 3, red. G. Kittel, Stuttgart 1938, s. 714. Podobnie jak „kerygmat”, również niemiecki termin „Verkündigung” może być tłumaczony jako nazwa głoszonego przesłania (wł. il messaggio proclamato) oraz sam akt proklamacji, czyli czynność głoszenia (wł. l'atto di proclamare). 
(por. Es 32, 5) albo natchnionym słowem proroka (por. Iz 61, 1) ${ }^{17}$. Podobnie jak w literaturze antycznej, tak też w Nowym Testamencie termin kerygmat służył na określenie zarówno nazwy głoszonego przesłania, jak i samego aktu proklamacji, czyli czynności głoszenia ${ }^{18}$. W wersetach Mt 12, 41; Łk 11, 32 termin kèrigma może być słusznie przetłumaczony jako łac. cohortatio, exhortatio, praedicatio $^{19}$. Natomiast $\mathrm{w}$ wersecie Tt 1, 3 termin kèrigma występuje w znaczeniu actus praedicandi $i^{20}$.

W formie rzeczownikowej wyraz kerygmat pojawia się w Nowym Testamencie dziewięć razy i oznacza jądro chrześcijańskiego Objawienia, centralne orędzie ogłaszające decydującą propozycję Boga dotyczącą zbawienia ludzi przez krzyżową śmierć, zmartwychwstanie i wniebowstąpienie Jezusa Chrystusa (Rz 16, 25; 1 Kor 1, 21; 15, 3-5.14). W tym sensie kerygmat uprzedza szczegółowe pouczenia o Panu Jezusie i o doktrynie chrześcijańskiej. Rzeczownik kerygmat oznacza też wezwanie do nawrócenia (Mt 12, 41; Łk 11, 32) ${ }^{21}$.

W formie czasownikowej, czyli jako słowo greckie kerýsso, kerys-

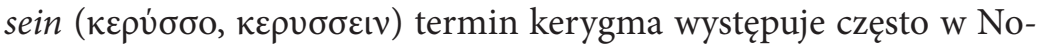
wym Testamencie. Oznacza on tyle, co „proklamować” i służy na określenie czynności przepowiadania słowa Bożego (łac. actus praedicandi), dzięki której słowo Boże (logos) dociera do człowieka przez posługę głosiciela (Tt 1, 3; $2 \mathrm{Tm} 4,5.17)$. Analizowane słowo obejmuje głoszenie chrześcijańskiego orędzia, Ewangelii, chrztu, królestwa Bożego, nawrócenia, odkupienia, czy też głoszenie Chrystusa ${ }^{22}$. Słowo to zakłada, że głosiciele Dobrej Nowiny „są heroldami, którzy

17 G. O'Collins, E. G. Farrugia, Leksykon pojęć teologicznych i kościelnych z indeksem angielsko-polskim, Kraków 2002, s. 122.

18 Por. A. Paciorek, Kerygmat w Biblii w: Encyklopedia Katolicka, Lublin 2008, t. 8, kol. 1360-1361.

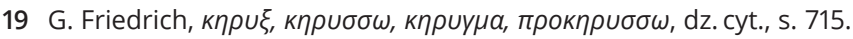

20 Tamże, s. 716.

21 Por. tamże.

22 Por. tamże, s. 695-714. 
po prostu zwiastują to, co zostało im powierzone do ogłoszenia, nie w swym w własnym imieniu, ale na mocy autorytetu tego, kto ich posyła" 23 .

Terminem bliskoznacznym dla „kerygmatu” jest „ewangelia”, czyli, zgodnie z etymologią, „Dobra Nowina”. Ewangelie mają kerygmatyczny charakter w tym sensie, że rozwijają proklamację kerygamatu ${ }^{24}$.

\subsection{Cechy kerygmatu}

Według św. Pawła, kerygmat jest „głupstwem”, które zbawia człowieka (por. 1 Kor 1, 21; Dz 13, 26). Kerygmat, jak to widać w Nowym Testamencie, przybiera nieco różne cechy w zależności od tego, do kogo jest kierowany: do żydów czy do pogan. Najpierw omówimy kerygmat do żydów, bo, historycznie ujmując, był on pierwszy.

\subsubsection{Kerygmat do żydów}

Przykładem kerygmatu skierowanego do żydów jest przepowiadanie samego Jezusa oraz przepowiadanie apostołów w postaci mów misyjnych (por. Dz 2, 14-39; 3, 12-26; 13, 16-41). Jezusowy kerygmat polegał na ogłaszaniu królestwa Bożego, które urzeczywistniło się w Nim samym, trwa w Kościele, a swoją pełnię osiągnie wraz z paruzją, czyli ponownym przyjściem Chrystusa na ziemię ${ }^{25}$. Z kolei kerygmat apostolski, czyli orędzie zawarte w apostolskich mowach misyjnych sprowadza się do głoszenia prawdy: o ziemskim posłannictwie Jezusa Chrystusa; o realizacji zapowiedzianego przez proroków Bożego planu zbawienia w Jezusie pochodzącym z rodu Dawida

23 J. L. McKenzie, Dictionary of the Bible, s. 689; cyt. za: FIYH 63, przyp. 85, s. 114.

24 Por. G. O'Collins, E. G. Farrugia, Leksykon pojęć teologicznych..., dz. cyt., s. 73, 122.

25 Por. S. Dyk, Przepowiadanie kerygmatyczne droga do zrodzenia wiary, "Przegląd Homiletyczny" 16 (2012), s. 45. 
(por. Dz 2, 16; 3, 22-24; 13, 23); o ukrzyżowaniu Jezusa ujawniającym ludzką niegodziwość; o wskrzeszeniu Jezusa z martwych przez Boga. Na kerygmat apostolski składa się także mesjańska interpretacja zmartwychwstania, czyli wykazanie, że wydarzenie to jest realizacją prorockich zapowiedzi ( $\mathrm{Dz} 2,24 \mathrm{~b}-36$; 13, 32-37). I wreszcie ważnym komponentem apostolskiego kerygmatu jest wezwanie słuchaczy do wiary, nawrócenia i chrztu. Taka odpowiedź na głoszony kerygmat jest wyrazem osobistego włączenia się człowieka w dzieło odkupienia za sprawą Ducha Świętego (por. Dz 2, 38; 3, 19-26; $13,37-39)^{26}$.

\subsubsection{Kerygmat do pogan}

Nieco inaczej głoszony był kerygmat apostolski do pogan. Najstarszy ślad tego kerygmatu znajdujemy w 1 Tes 1, 9-10. Apostoł chwalił chrześcijan w Tessalonikach za okazaną mu gościnność i za to, że nawrócili się od bożków do Boga, „by służyć Bogu żywemu i prawdziwemu i oczekiwać z niebios Jego Syna, którego wzbudził z martwych, Jezusa, naszego wybawcę od nadchodzącego gniewu" (1 Tes 1, 9-10) ${ }^{27}$.

Tekst ten zawiera dwie fundamentalne prawdy pierwotnego kerygmatu adresowanego do pogan: nawrócenie od służby bożkom ku jedynemu, żywemu i prawdziwemu Bogu, Stworzycielowi nieba i ziemi oraz jasne i otwarte zwiastowanie Dobrej Nowiny Jezusa Chrystusa. Przy czym przyjęcie kerygmatu zakłada uznanie apostoła za Bożego herolda ${ }^{28}$. Kerygmat skierowany do pogan jest więc wezwaniem do nawrócenia z politeizmu na monoteizm i do wiary w Jezusa jako Zbawiciela. Wiara w Jezusa Chrystusa oznacza przyjęcie prawdy o tym, że Bóg realizuje przez Niego zbawczy plan i w mocy Ducha Świętego czyni ludzi jego uczestnikami. Jezus z Nazaretu zasługuje

26 Por. tamże, s. 46.

27 Tamże, s. 42.

28 Por. tamże, s. 42-43. 
na wiarę, bo jest zapowiedzianym w Starym Testamencie Mesjaszem; Bóg Go wskrzesił z martwych, po tym jak został ukrzyżowany i umarł na krzyżu; Jezusa wybawia wierzących w Niego od potępienia i otwiera im drogę do życia wiecznego, dając w darze Ducha Świętego ${ }^{29}$. Te dwie podstawowe prawdy pierwotnego kerygmatu harmonizują z ewangelicznym początkiem Ewangelii Jezusa i zawartym w niej wezwaniem: „Nawracajcie się i wierzcie w Ewangelię” (Mk 1, 14; Mt 4, 17; por. Dz 20, 21) ${ }^{30}$.

Podsumowując cechy kerygmatu, należy stwierdzić, że:

- zawsze jest w nim zawarte orędzie o tym, iż Bóg ma wspaniały plan zbawienia wobec ludzi, a jego szczytem jest śmierć, zmartwychwstanie i uwielbienie Jezus Chrystusa. Kto uwierzy w Niego wraz z Nim będzie żył na wieki;

- kerygmat objawia Boga Ojca wszystkich ludzi, który przez Jezusa zaprasza do swego królestwa sprawiedliwości, miłości i pokoju;

- kerygmat to orędzie zbawienia dla każdego człowieka bez wyjątku (por. Rz 1,16), a zarazem wezwanie do wiary i nawrócenia, przez które uzyskuje się udział w Bożym planie zbawienia;

- kerygmat odsłania Boży zamysł dotyczący zjednoczenia wszystkich ludzi w Jezusie. Pierwszym doświadczeniem owego zjednoczenia jest życie we wspólnocie braci, których Duch Święty uczynił nowymi ludźmi ${ }^{31}$;

- różnica między kerygmatem kierowanym do żydów i do pogan jest taka, że w przypadku pierwszych adresatów kerygmat nie musiał zawierać wezwania do porzucenia politeizmu. Warto jeszcze zauważyć, że głoszenie kerygmatu Jezusa to nie tyle przekazywanie wiedzy o Jezusie, co doświadczenie mocy Jego słowa.

29 Por. tamże, s. 44.

30 Por. tamże, s. 42-43.

31 Por. tamże, s. 46-47. 
A więc to nie tylko proces dydaktyczny, ale przyjęcie bądź odrzucenie istotnej oferty dotyczącej całego życia człowieka.

Po omówieniu misterium Chrystusa oraz kerygmatu możemy przejść do analizy dogmatu. Wyjaśnienie tego terminu umożliwi nam przedstawienie roli kerygmatu i dogmatu w głoszeniu Chrystusowego misterium.

\section{Dogmat}

\subsection{Znaczenie terminu „dogmat”}

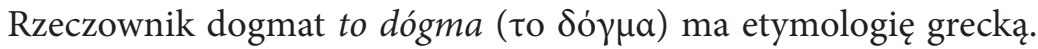
Wywodzi się z czasownika dokeo ( $о \kappa \varepsilon \omega, \delta о \kappa \varepsilon เ v)$. Czasownik ten wykorzystany został przez Homera w Iliadzie w znaczeniu „oczekiwać”, „myśleć”, „sądzić”, „mniemać”, „domyślać się”, „przypuszczać” oraz nieosobowo „wydawać się" ${ }^{32}$. Rzeczownik to dógma oznaczający „wytwór” czynności wyrażanej czasownikiem dokeo służy na określenie tego, co się myśli, sądzi, uważa.

Pierwotne znaczenie terminu zostało $\mathrm{z}$ czasem wzbogacone.

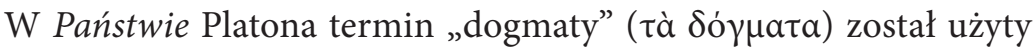
w znaczeniu zasad postępowania ${ }^{33}$. Z kolei w Prawach Platon wykorzystał termin „dogmat” w znaczeniu twierdzenia ${ }^{34}$. Zaś Filon z Aleksandrii (10 przed Chr. - 40 po Chr.), w dziele pod tytułem

32 Por. Słownik grecko-polski, red. O. Jurewicz, t. 1, Warszawa 2000, s. 226; Słownik grecko-polski, red. Z. Abramowiczówna, Warszawa 1958, t. 1, s. 592-593.

33 "Mamy od dziecięcych lat pewne tam zasady dotyczące tego, co sprawiedliwe i piękne" - Platon, Państwo 538c, w: tegoż, Państwo. Prawa, tłum. W. Witwicki, Kęty 1999, s. 247.

34 „To nie jest twierdzenie słuszne o księżycu i o słońcu, że błądzą kiedykolwiek. Rzecz się ma wprost przeciwnie. Każde z nich biegnie wciąż po tej samej drodze" - Platon, Prawa 822a, w: tegoż, Państwo. Prawa, dz. cyt., s. 500. 
O pijaństwie wykorzystał termin „dogmat” na oznaczenie doktryny ${ }^{35}$.

W Nowym Testamencie analizowany tu grecki termin dogmat ${ }^{36}$ występuje na przykład w znaczeniu edyktu władcy (por. Łk 2, 1; Hbr 11, 23; Dz 17, 7). W Liście św. Pawła do Kolosan (Kol 2, 14. 20) został wykorzystany na określenie przepisów o charakterze prawnym, a dokładniej nakazów. Z kolei w Liście św. Pawła do Efezjan termin dogmat dotyczy zarządzeń Prawa $($ Ef 2, 15) 37 .

Jedynym nowotestamentalnym tekstem, w którym termin dogmat występuje w sensie doktryny i zaleceń samego Jezusa, a więc w sensie bliskim temu, jak dziś go rozumiemy, jest fragment z Dziejów Apostolskich 16, 4, traktujący o postanowieniach, czyli dogmatach Kościoła jerozolimskiego, które należało zastosować w miastach ewangelizowanych przez Pawła i Tymoteusza ${ }^{38}$.

Rozróżnienie dwóch części chrześcijańskiego nauczania: tá

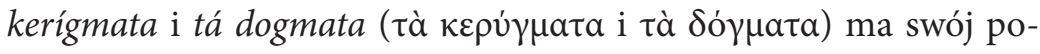
czątek w nauczaniu św. Bazylego Wielkiego biskupa Cezarei (330379). W Traktacie o Duchu Świętym Bazyli Wielki pisze o misterium jako Tradycji Apostolskiej przekazanej ustnie, a cieszącej się takim samym autorytetem jak zachowany przez Kościół tekst objawiony ${ }^{39}$.

35 Filon z Aleksandrii, O pijaństwie 198, w: tegoż, Pisma, t. 2, tłum. S. Kalinkowski, Kraków 1994, s. 149.

36 Por. Słownik grecko-polski, red. O. Jurewicz, t. 1, s. 226; Słownik grecko-polski, red. Z. Abramowiczówna, t. 1, s. 592-593.

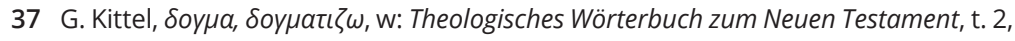
red. G. Kittel, Stuttgart 1935, s. 234; por. J. Drumm, Dogma, w: LTK, B. 3, k. 283.

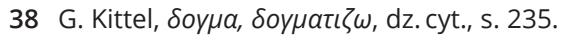

39 Por. Bazyli Wielki, Spir Sct 27, 66: MPG 32, 188a. Wśród ustnie przekazanych elementów Tradycji Apostolskiej Bazyli wymienia m.in.: czynienie znaku krzyża przez wyznawców Chrystusa; zwracanie się w stronę Wschodu podczas modlitwy; słowa wypowiadane nad chlebem eucharystycznym i kielichem, do których to ważności należy prefacja poprzedzająca słowa znane z Ewangelii i pism apostolskich a także słowa następujące po nich; wyrzekanie się Szatana i złych

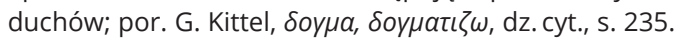


Uzasadnia nawet, że właśnie ustna Tradycja stoi na straży godności misterium, a zarazem chroni dogmat chrześcijański przed skażeniem. Potem zaś Bazyli stwierdza, że dogmat i kerygmat różnią się między sobą. Pierwszy jest zachowywany w ciszy, drugi jest proklamowany całemu światu ${ }^{40}$.

Omawiane pojęcie przeszło ewolucję. Termin dogmatídzo

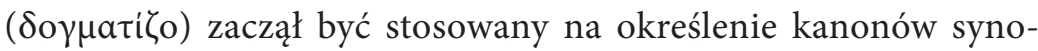

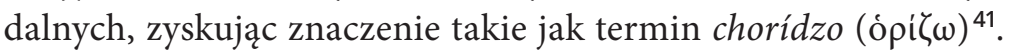

\subsection{Dogmat w teologii katolickiej}

Współcześnie „dogmat” w popularnym znaczeniu to nienaruszalna teza, pewnik, albo w węższym sensie - teza podana przez Kościół jako prawda do wierzenia. Według teologii katolickiej, dogmaty to prawdy zawarte w objawieniu Bożym lub prawdy, które mają z nimi konieczny związek, ogłoszone jako takie przez Urząd Nauczycielski Kościoła, na mocy władzy otrzymanej od Chrystusa, w formie zobowiązującej lud chrześcijański do nieodwołalnego przylgnięcia przez wiarę (por. KKK 88) ${ }^{42}$.

Pomimo swojego ogromnego znaczenia dogmaty nie są normą najwyższą, bo za taką uważane jest Pismo Święte zawierające Słowo Boże, celebrowane w liturgii (por. KO 21). Trzeba wszakże podkreślić, iż dogmaty Kościoła nie są dodatkowymi prawdami, niejako zewnętrznymi, dodanymi do Pisma Świętego i Tradycji, ale mają one swoje korzenie w Objawieniu. Mają one też swoją genezę i historię.

40 Przykładem takiego dogmatu jest zwracanie się chrześcijan w stronę Wschodu i modlitwy niedzielne w postawie stojącej - tamże.

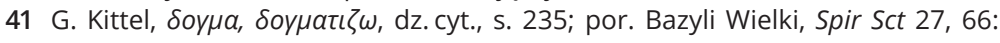
MPG 32, 188a.

42 G. O'Collins, E. G. Farrugia, Leksykon pojęć teologicznych..., s. 35. 
W tym sensie mówi się o rozwoju dogmatów. A jednak do natury orzeczenia dogmatycznego należy to, że zostaje ono uznane za definitywne. Sens dogmatu należy rozumieć w taki sposób, jak go wyjaśnia Urząd Nauczycielski Kościoła ${ }^{43}$. Dla przykładu, każde ortodoksyjne nauczanie o Chrystusie musi być zgodne z orzeczeniem Soboru w Nicei (325 rok) o bóstwie Wcielonego Syna Bożego. Wynika to ze wzajemnych związków i spójności dogmatów widocznej w całości Objawienia misterium Chrystusa (nexus mysteriorum) (por. KK 25; KKK 90). Przy czym poszczególne dogmaty posiadają różnorodny związek z podstawami wiary chrześcijańskiej, co decyduje o tym, że nie wszystkie prawdy mają taką samą wagę, lecz istnieje hierarchia prawd nauki katolickiej (DE 11; KKK 90).

Tak więc dogmat to definitywne orzeczenie Urzędu Nauczycielskiego Kościoła podawane jako prawda do wierzenia. Jej zaprzeczanie uznawane jest za herezję ${ }^{44}$. I trzeba podkreślić, że dogmaty ściśle wiążą się z życiem wierzących; „są światłem na drodze naszej wiary; oświecają ją i nadają jej pewność. I na odwrót, jeśli nasze życie jest prawe, to nasz rozum i nasze serce są otwarte na przyjęcie światła dogmatów wiary (por. J 8, 31-32)" (KKK 89).

Po wyjaśnienieniu ważnych w teologii terminów, jakimi są misterium Chrystusa, kerygmat i dogmat możemy podjąć dalszą refleksję nad ich znaczeniem w posłudze słowa.

43 H. Hoping, Die Wahrheit des Glaubens finden, „Die Tagespost” 36 (2015), s. 5.

44 Por. Kodeks prawa kanonicznego, kan. 750: „Wiarą boską i katolicką należy wierzyć w to wszystko, co jest zawarte w słowie Bożym, pisanym lub przekazanym, a więc w jednym depozycie wiary powierzonym Kościołowi i co równocześnie jako przez Boga objawione podaje do wierzenia Nauczycielski Urząd Kościoła, czy to w uroczystym orzeczeniu, czy też w zwyczajnym i powszechnym nauczaniu; co mianowicie ujawnia się we wspólnym uznaniu wiernych pod kierownictwem świętego Urzędu Nauczycielskiego. Wszyscy więc obowiązani są unikać doktryn temu przeciwnych". 


\section{Znaczenie kerygmatu i dogmatu w głoszeniu misterium Chrystusa}

Zastanawiając się nad znaczeniem kerygmatu i dogmatu w głoszeniu misterium Chrystusa należy podkreślić zróżnicowanie form przepowiadania. W każdej z nich bowiem nieco inaczej eksponowana jest rola kerygmatu i dogmatu.

\subsection{Różne formy przepowiadania}

Dyrektorium ogólne o katechizacji wymienia następujące formy posługi słowa: 1) ewangelizację, czyli zwołanie i powołanie do wiary i wspólnoty; 2) katechezę mistagogiczną, czyli wtajemniczenie - inicjację; 3) katechezę permanentną, czyli stałe wychowanie w wierze; 4) przepowiadanie liturgiczne, a w nim homilię; 5) pouczenie teologiczne $^{45}$. W każdej z tych form posługi słowa zarówno kerygmat, jak i dogmat odgrywają ważną rolę, ale w jednych bardziej wyeksponowany jest kerygmat, a w innych dogmat.

1. Ewangelizacja, czyli zwołanie i powołanie do wiary i wspólnoty, to pierwsze przepowiadanie będące wykonaniem misyjnego polecenia Pana Jezusa. Ewangelizacja jest skierowana do niewierzących, czyli do tych, którzy nigdy nie wierzyli w Boga i wybrali niewiarę; a także do chrześcijan, którzy zerwali więź z Chrystusem i Kościołem, oraz do tych, którzy wyznają i praktykują inne poglądy religijne. Funkcją pierwszego przepowiadania jest także budzenie wiary u dzieci w rodzinach chrześcijańskich.

45 Kongregacja ds. Duchowieństwa, Dyrektorium Ogólne o Katechizacji, Poznań 1998, nr 51, s. 43. http://www.vatican.va/roman_curia/congregations/cclergy/documents/rc_con_ccatheduc_doc_17041998_directory-for-catechesis_en.html (dostęp: 11.1.2017). 
2. Katecheza mistagogiczna, czyli wtajemniczenie albo inicjacja do wiary, to głoszenie Ewangelii skierowane do osób poruszonych łaską i zdecydowanych na życie w sakramentalnej jedności z Jezusem we wspólnocie Kościoła. Głoszenie słowa Bożego do tych osób połączone jest ściśle $\mathrm{z}$ wprowadzeniem ich w życie wiary, w liturgię oraz praktykę miłości. Służy temu katecheza związaną z sakramentami inicjacji chrześcijańskiej już przyjętymi albo oczekiwanymi. Forma ta obejmuje zarówno inicjację chrześcijańską dzieci i młodzieży, jak też katechezę dorosłych nieochrzczonych realizowaną przez katechumenat, a nawet katechezę dorosłych już ochrzczonych, którzy chcą powrócić do wiary wcześniej porzuconej bądź też dokończyć etap wtajemniczenia. Funkcji tej służy wychowanie religijne w rodzinach i nauczanie religii w szkołach.

3. Katecheza permanentna, czyli stałe wychowanie w wierze, jest głoszeniem Ewangelii do chrześcijan, którzy już zostali wprowadzeni w podstawy wiary chrześcijańskiej, ale potrzebują systematycznego ożywiania i pogłębiania wiary. Funkcji tej służą na przykład konferencje rekolekcyjne oraz konferencje o tematyce religijnej.

4. Przepowiadanie liturgiczne skierowane jest do osób wierzących, którzy uczestniczą w obrzędach chrześcijańskich. Dokonuje się ono podczas liturgii jako jej integralna część. Najważniejszą postacią przepowiadania liturgicznego jest homilia. Jest ono realizowane także przez pouczenia w trakcie sprawowania sakramentów, sakramentaliów i celebracji Liturgii godzin.

5. Pouczenie teologiczne jest przepowiadaniem adresowanym do osób, które pragną lepiej zrozumieć, w co wierzą, zgodnie z dynamiką fides quaerens intellectum - wiary szukającej zrozumienia. W tym przypadku przepowiadanie uwzględnia kontekst filozoficznych debat i wyzwania dla wiary płynące ze strony nauk o człowieku. Obejmuje ono zarówno elementy apologetyczne, jak i konfrontację z poglądami filozoficznymi i naukowymi. Ta forma przepowiadania znajduje swój wyraz w systematycznych i naukowych konferencjach na temat 
prawd wiary (Kongregacja ds. Duchowieństwa, Dyrektorium ogólne o katechizacji, 51).

Jakkolwiek między wymienionymi formami posługi słowa zachodzą różnice, to jednak trzeba pamiętać, że żadna $\mathrm{z}$ nich nie pozostaje całkowicie niezależna od pozostałych. O ich fundamentalnej jedności decyduje fakt, że wszystkie służą głoszeniu misterium Chrystusa. Pomimo zróżnicowania form jedna jest posługa przepowiadania Dobrej Nowiny Jezusa Chrystusa ${ }^{46}$.

\subsection{Kerygmat w przepowiadaniu}

Kerygmat jest potrzebny na każdym etapie wtajemniczenia chrześcijańskiego i formacji chrześcijańskiej, w różnych formach posługi słowa, ale jego nasilenie jest zróżnicowane. Kerygmat dominuje przede wszystkim w ewangelizacji. W niej bowiem głoszone jest podstawowe orędzie chrześcijańskie. We wtajemniczeniu i w przepowiadaniu liturgicznym jest on przeżywany, rozwijany i uzupełniany o wyjaśnienia doktrynalne, a w katechezie permanentnej oraz w pouczeniu teologicznym kerygmat jest obecny w znacznie mniejszym stopniu, ustępując miejsca wyjaśnieniu doktrynalnemu.

Kerygmat był i pozostaje główną zawartością kościelnego przepowiadania. „Gdyby było inaczej, Kościół utraciłby związek z kerygmatem apostolskim, sprzeniewierzyłby się swej zasadniczej misji, a może nawet dawno przestałby istnieć" ${ }^{47}$. Chociaż więc niekwestionowana jest ważność kerygmatu w przepowiadaniu Kościoła nie da się całego przepowiadania sprowadzić tylko do niego. Istnieją bowiem, o czym wcześniej była mowa, różne formy przepowiadania, które różnią się

46 Por. D. Grasso, Proclaiming God's message. A study in the theology of preaching, Notre Dame 1965, s. 232; H. Sławiński, Rola homilii w liturgii Kościoła, „Studia Włocławskie" 4 (2001), s. 289-303.

47 G. Siwek, Blaski i cienie współczesnego przepowiadania, s. 59. 
między sobą, ale się wzajemnie uzupełniają i przenikają. Nie należy zacierać różnic między nimi ani też przeciwstawiać ich sobie. Nie da się bowiem zadecydować w praktyce o tym, że w danym środowisku kończy się głoszenie kerygmatu, a zaczyna usystematyzowane wyjaśnianie dogmatów Kościoła.

Kerygmat domaga się rozwinięcia. I tu z pomocą przychodzi dogmat analizowany i opracowany przez teologię systematyczną. Tak więc najbardziej skondensowanym wyrazem misterium Chrystusa jest kerygmat, a najbardziej usystematyzowanym i precyzyjnym wyrazem misterium Chrystusa jest dogmat. Spełnia on w przepowiadaniu podwójną rolę: 1) pozytywną, konstruktywną, dostarczając treści do głoszenia - stąd też głosiciele słowa Bożego są powołani do bycia teologami; 2) krytyczną, chroniąc przed głoszeniem nauczenia błędnego, niepełnego lub zniekształconego ${ }^{48}$.

\subsection{Pozytywna rola dogmatu w przepowiadaniu}

Głosiciele słowa Bożego są teologami i duszpasterzami powołanymi do głoszenia prawdy zbawczej w trosce o dojrzałą wiarę wiernych powierzonych swej opiece. Wiara zaś oznacza zarówno akt wiary, jak i treści wiary. Stąd rozróżnia się wierzenie Jezusowi (fides quae creditur) i wierzenie w Jezusa (fides qua creditur). Wierzenie Jezusowi to dobrowolne uznanie prawd, które nam przekazał jako Bóg-Człowiek, a wiara w Jezusa to akt wiary. Wiara jest więc zarówno osobowym przylgnięciem człowieka do Boga, jak też uznaniem prawdy, którą On objawił najpełniej w swoim Synu, Jezusie Chrystusie (por. KKK 150). A ponieważ między aktem wiary a jej dobrowolnie przyjmowaną treścią istnieje nierozdzielna więź, niezbędne jest głoszenie prawdy

48 Por. M. C. Hilkert, Preaching and theology: rethinking the relationship, "Worship" 65 (1991) nr 5, s. 399. 
objawionej i podanej przez Kościół do wierzenia. Na straży czystości tej prawdy stoją dogmaty Kościoła. One nadają pewność wierze. Z tym, że w przepowiadaniu Kościoła głosimy nie dogmaty, lecz misterium Chrystusa, które jest obecne i działa w życiu Jego wyznawców.

Znając dogmaty Kościoła, głosiciel słowa Bożego ma za zadanie „rozjaśniać światłem wiary nowe sytuacje i problemy, które w przeszłości nie istniały" (FD). Podejmuje refleksję teologiczną nad doświadczeniami, które przeżywają wierni; łączy chrześcijańską tradycję ze współczesnym doświadczeniem ludzkim. Stoi też zawsze przed wyzwaniem wyrażenia dogmatów Kościoła za pomocą współczesnych obrazów i języka zrozumiałego dla słuchaczy. Wiara bowiem nie dotyczy formuł i nie odnosi się do tego, co się wypowiada, ale do rzeczywistości wyrażonej za pomocą formuł. Głosiciel słowa Bożego, za pomocą formuł wiary, wyraża i przekazuje wiarę oraz ułatwia wiernym jej celebrowanie we wspólnocie, przyswojenie jej sobie i życie zgodnie z nią (por. KKK 170). Zadanie głosiciela słowa Bożego sięga więc dalej niż zadanie teologa: nie tylko wyjaśnia on prawdy wiary, ale wprowadza w misterium, wskazuje na obecność Boga w celebrowanych obrzędach liturgicznych.

Biskupi amerykańscy w dokumencie Preaching the Mistery of Faith zauważyli: „Magisterium Kościoła, inspirowane wiarą i kierownictwem Ducha Świętego, widzi w teologii i dogmacie nie zagrożenie, ale przewodników dających klarowną interpretację Biblii, wiarygodne wyjaśnienia autentycznego znaczenia tekstów biblijnych. W związku z tym Kościół zachęca egzegetów i głosicieli słowa, aby podchodzili do Biblii z żywym poczuciem istotnej jedności tekstu świętego, a także z dowartościowaniem tego, jak Logos, Jezus Chrystus - teologicznie wyrażony i rozwinięty w przekazie świętej Tradycji - dostarcza właściwego pryzmatu interpretacyjnego dla całego Pisma Świętego" ${ }^{49}$.

49 Konferencja Biskupów Katolickich Stanów Zjednoczonych, Przepowiadanie misterium wiary. Homilia niedzielna, w: Homilia niedzielna. Dokumenty Konferencji 


\subsection{Krytyczna rola dogmatu w przepowiadaniu}

Oprócz swojej pozytywnej roli w przepowiadaniu dogmat spełnia ponadto rolę krytyczną, w tym sensie, że chroni przepowiadanie misterium Chrystusa przed błędami, uszczupleniem lub zniekształceniem. Wierność dogmatom chroni głosiciela słowa Bożego przed popadaniem w herezję, którą Kodeks prawa kanonicznego definiuje jako „uporczywe, po przyjęciu chrztu, zaprzeczanie jakiejś prawdzie, w którą należy wierzyć wiarą boską i katolicką, albo uporczywe powątpiewanie o niej” (KPK, kan. 751).

Bywają okoliczności, w których bardzo pożądane jest wyjaśnienie doktryny Kościoła. Potrzebne jest wówczas przepowiadanie doktrynalne i apologetyczne. Niekiedy jest ono realizowane w postaci listów pasterskich. Jednakże - trzeba to mocno podkreślić - liturgia nie jest najodpowiedniejszym momentem do systematycznego wykładu doktryny Kościoła. Niemniej jednak również głosiciel homilii jako integralnej części liturgii korzysta z krytycznej roli dogmatu. $\mathrm{Na}$ przykład, mając świadomość stanowiska Kościoła wobec pelagianizmu, uniknie semipelagianizmu charakteryzującego tych, którzy wierzą, że inicjatywa zbawienia zależy od rozwoju i postępu duchowego. Z kolei, znając stanowiska Kościoła wobec monofizytyzmu uniknie kryptomonofizytyzmu typowego dla tych, który nie do końca wierzą w człowieczeństwo Jezusa ${ }^{50}$. Jest to aktualnie realne niebezpieczeństwo, które dostrzegł papież Franciszek i dlatego w adhortacji Evangelii gaudium napisał: „Dzisiaj, bardziej niż przed wyzwaniem ateizmu, stajemy przed wyzwaniem, by odpowiedzieć właściwie na pragnienie Boga u wielu ludzi, by nie starali się ugasić go przez wyobcowane propozycje lub przez Jezusa bez ciała i bez zaangażowania się na rzecz drugiego człowieka” (EG 89).

Episkopatu Stanów Zjednoczonych, przekł., oprac. i red. H. Sławiński, Kraków 2015, nr 108, s. 84 (Ancilla Verbi, 3).

50 Por. M. C. Hilkert, Preaching and theology, dz. cyt., s. 402. 
Dogmaty spełniają w przepowiadaniu funkcję krytyczną także wtedy, gdy chronią przed niepełnym przedstawianiem misterium Chrystusa. Można bowiem minąć się z prawdą Ewangelii przez głoszenie półprawd, bo podjęcie zagadnień moralnych czy związanych ze sprawiedliwością społeczną może się wydawać zbyt kontrowersyjne albo zbyt trudne w nawiązaniu do orędzia danego dnia ${ }^{51}$.

I wreszcie dogmat chroni nie tylko przed przepowiadaniem błędnym czy niepełnym, ale także przez przepowiadaniem zniekształconym, a do takiego dochodzi wówczas, gdy nie jest respektowana hierarchia prawd w nauce katolickiej. Pominięcie owej hierarchii przejawia się w tym, że prawdy peryferyjne wypierają prawdy główne w przepowiadaniu. Papież Franciszek ilustruje tak zniekształcone przepowiadanie następującymi przykładami:

[...] jeśli jakiś proboszcz podczas roku liturgicznego mówi dziesięć razy o wstrzemięźliwości, a tylko dwa lub trzy razy o miłości czy sprawiedliwości, dochodzi do dysproporcji, przez co pozostawione są właśnie te cnoty, które powinny być bardziej obecne w przepowiadaniu i katechezie. To samo ma miejsce, gdy bardziej się mówi o prawie niż o łasce, bardziej o Kościele niż o Jezusie Chrystusie, bardziej o papieżu niż o Słowie Bożym [...]. Kiedy przepowiadanie pozostaje wierne Ewangelii, widać wyraźnie centralny charakter niektórych prawd [...]. Ewangelia przede wszystkim zaprasza, byśmy odpowiedzieli Bogu, który nas kocha i nas zbawia, rozpoznając Go w innych i wychodząc poza samych siebie, by szukać dobra wszystkich [...]. Jeśli to zaproszenie nie jaśnieje z mocą i jako pociągające, moralna budowla Kościoła narażona jest na ryzyko stania się papierowym zamkiem, $i$ to jest nasze najgorsze niebezpieczeństwo. Ponieważ, ściśle mówiąc, nie będzie wtedy głoszona Ewangelia, lecz niektóre akcenty doktrynalne 
lub moralne wywodzące się z określonych opcji ideologicznych. Orędzie będzie narażone na utratę swej świeżości i nie będzie już miało „zapachu Ewangelii”. (EG 38-39)

Warto jeszcze zauważyć, że język przepowiadania różni się od języka dogmatów. Ten pierwszy, czyli język przepowiadania słowa Bożego jest symboliczny i poetycki, tzn. dociera do słuchaczy na wielu poziomach świadomości, ułatwiając przeżycie religijne. Ten drugi, czyli język sformułowań dogmatycznych jest precyzyjny, a przez to skomplikowany: on nie zmierza do wywołania religijnego przeżycia, a jedynie do rozumowego objaśnienia prawd wiary. Inaczej mówiąc, przepowiadanie, zwłaszcza homilijne, będąc wierne dogmatom, wyraża doktrynę Kościoła, ale w sposób mistagogiczny, właściwy dla kontekstu liturgicznego ${ }^{52}$.

\subsection{Centralna rola głoszenia misterium Chrystusa}

Nie można oddzielać kerygmatu jako skondensowanego orędzia chrześcijańskiego od pogłębionej refleksji nad nim w postaci egzegezy, refleksji nad dogmatami wiary i przepowiadania. Wszystko ma służyć głoszeniu Chrystusowego misterium, które jest w nas obecne i działa. Trzeba tu jednak wyraźnie powiedzieć, że „ponieważ istnieje przepowiadanie, przeto istnieje też teologia: nie vice versa" ${ }^{\text {"3 }}$. Usystematyzowana refleksja teologiczna służy przepowiadaniu. Przepowiadanie Kościoła nie ogranicza się do głoszenia kerygmatu czy dogmatu. Można natomiast mówić, że Kościół głosi misterium Chrystusa. Kerygmat stanowi jądro, zasadnicze orędzie głoszonego misterium Chrystusa. Dogmat wyraża głoszone misterium Chrystusa w precyzyjnych sformułowaniach,

52 Tamże, s. 404.

53 K. Rahner, Priest and poet, theological investigation, v. 3, tr. K. H. Kruger, B. Kruger, Baltimore 1967, s. 305. 
które są pewnymi prawdami wiary - dają pewność wierze. Ostatecznie jednak głosimy Chrystusa jako Pana i Zbawiciela.

Z tego względu szczytową postacią przepowiadania Kościoła jest homilia rozumiana jako integralna część liturgii. Według soborowej konstytucji Sacrosanctum concilium (KL 35, 2), homilia jest zwiastowaniem misterium Chrystusa. A zatem misterium to stanowi treść homilii i jest przedstawiane wiernym $\mathrm{w}$ całości z biegiem roku liturgicznego ${ }^{54}$. Taka metoda pozwala wiernym skupić uwagę na poszczególnych wydarzeniach zbawczych, składających się na całe misterium Chrystusa celebrowane i przekazywane w liturgii oraz głoszone w homilii (por. KKK 1163; FD). Misterium, czyli tajemnicę Chrystusa należy w posłudze słowa przedstawiać w całości i wiernie na podstawie źródeł, jakimi są: Pismo święte, Tradycja, liturgia, Nauczycielski Urząd i życie Kościoła (por. KPK, kan. 760). W głoszeniu misterium Chrystusa pomaga ponadto poznanie duchowego dziedzictwa ojców, doktorów i świętych Kościoła oraz wyjaśnień „nauki, które w ciągu dziejów Duch Święty wskazał Kościołowi” (por. FD). Nie głosimy jednak ani czytań biblijnych, ani dogmatów, ale na ich podstawie głosimy Chrystusa obecnego i działającego w sprawowanym misterium. Zrozumienie tego faktu ma znaczenie praktyczne. Głosiciel homilii nie będzie wyjaśniał czytań, ale będzie mówił o Chrystusie żywym i działającym w Kościele: od początku historii zbawienia po aktualnie sprawowane obrzędy liturgiczne.

\section{Podsumowanie}

Kościół otrzymał od swojego Założyciela zadanie głoszenia Ewangelii wszystkim narodom. Wypełnia to zadanie głosząc kerygmat, czyli

54 „Rok liturgiczny jest rozwinięciem różnych aspektów jedynego misterium paschalnego" - KKK 1171; por. KL 102. 
najbardziej skondensowane orędzie, które niesie apel i wyzwanie do słuchaczy, aby przyjęli darmo daną ofertę zbawienia. Kerygmat jest niezbędny na każdym etapie wtajemniczenia chrześcijańskiego i permanentnej formacji chrześcijańskiej. Ale jest on niewystarczający i domaga się rozwinięcia przez pogłębioną myśl teologiczną. Ta $\mathrm{z}$ kolei jest najprecyzyjniej wyrażona $\mathrm{w}$ dogmatach i przekazywana w Tradycji apostolskiej oraz przez Urząd Nauczycielski Kościoła. Pełni ona bardzo ważną rolę w przepowiadaniu - służy pogłębieniu kerygmatu: od strony pozytywnej rzuca światło wiary na wciąż nowe i aktualne sytuacje i problemy dotyczące życia wierzących; od strony krytycznej chroni przepowiadanie słowa Bożego przed błędami, uszczupleniem lub zniekształceniem. Zarówno kerygmat, jak i dogmat służą proklamacji misterium Chrystusa, który jest obecny i działa w Kościele i w świecie.

\section{Misterium Chrystusa, kerygmat i dogmat w przepowiadaniu}

Streszczenie

Wypełniając wolę swojego Założyciela, Jezusa Chrystusa, Kościół głosi Ewangelię wszystkim narodom. Żydom zwiastuje Jezusa Chrystusa jako Mesjasza zapowiedzianego w Starym Przymierzu; pogan wzywa dodatkowo, by porzucili służbę bożkom i podporządkowali swoją wolę jedynemu prawdziwemu Bogu. Podstawowy kerygmat o zbawieniu rozwijany jest w nauczaniu Kościoła, który precyzuje treści wiary w dogmatach. Głosiciel słowa Bożego, znając dogmaty Kościoła, rozjaśnia światłem wiary aktualne sytuacje i problemy słuchaczy. Ponadto znajomość dogmatów Kościoła chroni głosiciela przed błędnym nauczaniem. I kerygmat, i dogmat mają swoje miejsce w przepowiadaniu, które jest zwiastowaniem misterium Jezusa Chrystusa.

Słowa kluczowe

Chrystus, Misterium, kerygmat, dogmat, przepowiadanie 


\section{The Mystery of Christ: Kerygma and Dogma in Preaching}

Summary

The Church, fulfilling the will of her founder, Jesus Christ, proclaims the Gospel to all nations. To the Jews, Jesus Christ is proclaimed by the Church as the Messiah announced in the Old Covenant. The Gentiles are called to abandon the worship of idols and to surrender their will to the one true God. The basic kerygma of salvation is developed in the teaching of the Church, which specifies the content of the faith in dogma. The preacher of the word of God, knowing the dogmas of the Church, illuminates, with the light of faith, the current situation and problems of listeners. In addition, the knowledge of the dogmas of the Church protects the preacher against false teaching. Both kerygma and dogma have their place in preaching, which is intrinsically a proclamation of the mystery of Jesus Christ.

Keywords

Christ, Mystery, Kerygma, Dogma, Preaching

\section{Bibliografia}

Benedykt XVI, adhort. apost. Sacramentum caritatis (22.02.2007).

Benedykt XVI, adhort. apost. Verbum Domini (30.09.2010).

Carl III W. J., Preaching Christian doctrine, Philadelphia 1984.

Czerwik S., Homilia o misterium (misteriach) Chrystusa w cyklu roku liturgicznego, „Przegląd Homiletyczny" 8 (2004), s. 45-57.

Drumm J., Dogma, w: Lexikon für Theologie und Kirche, t. 3, Hrsg. W. Kasper, Freiburg-Basel-Rom-Wien 1995, k. 283-286.

Dyk S., Przepowiadanie kerygmatyczne droga do zrodzenia wiary , „Przegląd Homiletyczny" 16 (2012), s. 41-54.

Dyk S., Znaczenie terminu „misterium” w refleksji teologiczno-liturgicznej, „Roczniki Liturgiczno-Homiletyczne" 56 (2009) 1, s. 69-85.

Filon z Aleksandrii, Pisma, t. 2, tłum. S. Kalinkowski, Kraków 1994.

Franciszek, adhort. apost. Evangelii gaudium (24.11.2013).

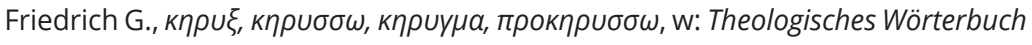
zum Neuen Testament, t. 3, red. G. Kittel, Stuttgart 1938, s. 682-717. 
Gerardi R., Misterio, w: Diccionario teológico enciclopédico, red. L. Pacomi, V. Mancuso, Villatuerta 1995, s. 642-643.

Grasso D., Proclaiming God's message. A study in the theology of preaching, Notre Dame, 1965.

Hilkert M. C., Preaching and theology: rethinking the relationship, "Worship" 65 (1991) 5, s. 398-409.

Hoping H., Die Wahrheit des Glaubens finden, „Die Tagespost” 36 (2015), s. 5. Jan Paweł II, Katechizm Kościoła Katolickiego (11.10.1992), Poznań 1994.

Jan Paweł II, konst. apost. Fidei depositum w: Katechizm Kościoła Katolickiego, Poznań 1994, s. 5-9.

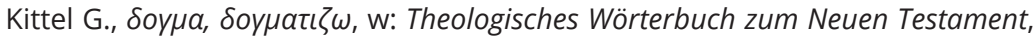
t. 2, red. G. Kittel, Stuttgart 1935, s. 233-235.

Kodeks prawa kanonicznego, Poznań 1983.

Komisja do Spraw Życia i Posługi Kapłanów przy Krajowej Konferencji Biskupów Katolickich Stanów Zjednoczonych, Fulfilled in your hearing. The homily in the Sunday assembly, Washington 1982; tekst polski: „Dziś spełniły się słowa Pisma?". Homilia w niedzielnym zgromadzeniu wiernych, w: Homilia niedzielna. Dokumenty Konferencji Episkopatu Stanów Zjednoczonych, przekł. oprac. i red. H. Sławiński, Kraków 2015, s. 89-135 (Ancilla Verbi, 3).

Konferencja Biskupów Katolickich Stanów Zjednoczonych, Preaching the Mistery of Faith, tekst polski: Przepowiadanie misterium wiary. Homilia niedzielna, w: Homilia niedzielna. Dokumenty Konferencji Episkopatu Stanów Zjednoczonych, przekł. oprac. i red. H. Sławiński, Kraków 2015, s. 29-88 (Ancilla Verbi, 3). Kongregacja ds. Duchowieństwa, Dyrektorium ogólne o katechizacji, Poznań 1998. http://www.vatican.va/roman_curia/congregations/cclergy/documents/rc_ con_ccatheduc_doc_17041998_directory-for-catechesis_en.html (dostęp: 11.1.2017).

Kudasiewicz J., Homilie na święta Pańskie a problem synoptyczny , „Przegląd Homiletyczny" 8 (2004), s. 33-44.

Nadolski B., Leksykon liturgii, Poznań 2002.

O'Collins G., Farrugia E. G., Leksykon pojęć teologicznych i kościelnych z indeksem angielsko-polskim, Kraków 2002.

Paciorek A., Kerygmat w Biblii, w: Encyklopedia Katolicka, Lublin 2008, t. 8, kol. 1360-1361.

Platon, Państwo. Prawa, tłum. W. Witwicki, Kęty 1999.

Rahner K., Priest and poet, theological investigation, v. 3, tr. K. H. Kruger, B. Kruger, Baltimore 1967. 
Ratzinger J. - Benedykt XVI, Jezus z Nazaretu, cz. 1: Od Chrztu w Jordanie do Przemienienia, Kraków 2007.

Siwek G., Blaski i cienie współczesnego przepowiadania. Przewodnik dla kaznodziejów i homilistów, Kraków 2007.

Sławiński H., Między ciagłościq a zmianq. Teoria homilii w Stanach Zjednoczonych po Il Soborze Watykańskim, Kraków 2008.

Sławiński H., Rola homilii w liturgii Kościoła, "Studia Włocławskie” 4 (2001), s. 289-303.

Słownik grecko-polski, red. O. Jurewicz, t. 1, Warszawa 2000.

Słownik grecko-polski, red. Z. Abramowiczówna, t. 1, Warszawa 1958.

Sobór Watykański II, dekr. Unitatis redintegratio (21.11.1964).

Sobór Watykański II, konst. Lumen gentium (21.11.1964).

Sobór Watykański II, konst. Dei Verbum (18.11.1965).

Sobór Watykański II, konst. Sacrosanctum Concilium (04.12.1963).

Wallace J. A., Imaginal preaching. An archetypal perspective, New York-Mahwah 1995. 